\title{
Regional case study of Sustainable Development Goals implementation: Informal education and third mission of universities
}

\author{
Sayana Vologzhina ${ }^{1}$, Natalya Ryazanova ${ }^{2}$, Vasily Eroshenko ${ }^{3}$ \\ ${ }^{1}$ Irkutsk State University, 664003, 1, Karl Marx st., Irkutsk, Russia, \\ ${ }^{2}$ Moscow State Institute of International Relations (MGIMO University), Department of Integrated \\ International Ecological Problems and Wildlife Management, 119454, 76 Vernadskogo prospect, \\ Moscow, Russia \\ ${ }^{3}$ Moscow Pedagogical State University, 119991, 1, building 1, Malaya Pirogovskaya st., Moscow, \\ Russia
}

\begin{abstract}
The aim of the study is to introduce practical experience and explore the possibilities of sustainable development ideology in the region and to involve youth activists in international processes of regional reflection. Objectives: research of possibilities of youth organizations and universities in realization of non-formal education for overcoming environmental problems in the region; development of practical experience in realization of environmental education for sustainable development (ESD); development of pedagogical technology for non-formal work; creation of pedagogical model of interaction of different segments of youth organizations. Methodology: creation of the World Water Forum youth model. Work directions: adaptation of the international agenda to the regional one (Baikal region) and creation of the pedagogical model of practice-oriented work of youth communities for implementation of the third mission of HEIs. Regional ministries, youth government of Irkutsk region, colleges and universities of the region were involved in the model development. As a result of the thematic groups' work, an inventory of the region's problems was made by the activities of each working group; lists of the most promising areas of work to improve the environmental and social situation in the region were compiled; and road maps to achieve the set goals for up to 5 years were developed.
\end{abstract}

\section{Introduction}

The relevance of the study was to order the region to attract research work of colleges and universities, aimed at taking into account the importance of youth practices and grant work for real work to improve the environmental situation in the region. The Baikal region is a part of the UNESCO program of the World Natural and Cultural Heritage and in 2017 on the international level began to discuss the obvious lack of work and attention of the regional government on the conservation of Baikal and significant degradation of the Baikal territory. In this regard, proposals were made to remove the Baikal from the programme and strip it of its natural World Heritage status. The new government of the region was very concerned 
about this and appealed to local educational organizations to raise the level of university science and expertise so that grant research has practical, not only theoretical significance.

In addition, a Youth Government has been established in the region, which should become a real personnel reserve for the current generation of officials and politicians.

The essence of the program was to combine the capabilities of youth communities from different sectors: educational, public administration, political and non-profit organizations.

The main research practice was based on Agile ideology and eduScrum methodology. Scientific institutions of the region provided their expertise in the preparation of the WWF Model and scientific research conducted during the previous 5-7 years on the Baikal territory to improve the quality and maximize the approach of prepared youth solutions and proposals to the needs of the region. The scientific research was combined with social and political practices.

This work differed so much from the previous ones, that scientific organizations and the government spoke about it at the regional level as the first practice of socially responsible policy and the first practical experience of achieving SDG indicators in the region. The setting of tasks and proposed solutions for the first time "came out of the office into people".

Research hypothesis: universities and young people can act as a mediator between regional governments, academia and the public and gain valuable practical experience in working with information, creating a regional strategy and roadmaps for achieving them.

Rapidly changing environments have shaped the concept of Life Long Learning, where people are forced to learn permanently, thus creating a new culture and new approaches to education [1]. The project-based approach to learning allows us to take a completely new look at the very process of forming practice-oriented competencies of future specialists and to concern the teaching staff with the question: "Does the university fulfill its social responsibility to the needs of the region? It is this direction of HEIs activity that actualizes economic and legal aspects of HEIs support by business and state structures in the region. The same theme feeds the educational process with actual information from scientific institutions. Social responsibility makes it possible to include more actively the socially important agenda, on which NPOs in the region work, into the educational practices of students.

Such work to move the international agenda to the regional level, to create a methodology for step-by-step work and to achieve the desired result was almost the first time. The real long-term experience of youth modeling was developed within the framework of the work of the Russian UN Association in the form of the UN Youth Model. However, within the framework of this event the real international process (work of UN committees and commissions, but not the regional Russian agenda) is modeled.

\section{Methods and materials}

The method of work was based on the Agile approach due to its great complexity and many uncertainties [3-5]. The educational paradigm in the process approach formed congruent competences and the ability to work with texts and partners, in the project approach promoted the formation of personality and was directed at an activity-oriented paradigm.

The main technologies: personality and activity training in the method of foresight design; cognitive instruction - in the form of a directed process of step-by-step implementation of the project under the guidance of a tutor; technology of development training allowed to eliminate the fear of young people before state reports and documents and scientific literature written in complex language. Great resource potential was used in the form of scientificmethodical, reporting, reference, educational literature, international documents and media creation, which were filled in the process of the project implementation. 
Table 1. Main steps of project activity implementation

\begin{tabular}{|c|c|c|}
\hline $\begin{array}{c}\text { Steps on the } \\
\text { project }\end{array}$ & Pedagogical technologies & Project activity result \\
\hline $\begin{array}{l}\text { Step 1: Inventory } \\
\text { of environmental } \\
\text { problems in the } \\
\text { region }\end{array}$ & $\begin{array}{l}\text { Ecological-humanistic } \\
\text { Ecological development } \\
\text { ecosystem thinking, cognitive activity. }\end{array}$ & $\begin{array}{l}\text { A relatively complete list of obvious } \\
\text { and non-obvious, but local problems } \\
\text { in the region has been compiled }\end{array}$ \\
\hline $\begin{array}{l}\text { Step 2: Literary } \\
\text { review and } \\
\text { retrospective } \\
\text { analysis }\end{array}$ & $\begin{array}{l}\text { Establishment of environmental } \\
\text { thinking }\end{array}$ & $\begin{array}{l}\text { A thematic catalogue of literature on } \\
\text { the directions of environmental } \\
\text { problems identified in Step } 1 \text { has been } \\
\text { compiled. It is structured by the } \\
\text { directions: state documents, scientific } \\
\text { literature, mass media information. } \\
\text { The general level of study of the } \\
\text { problem and its perception by } \\
\text { residents of the region, at the federal } \\
\text { level by authorities, at the } \\
\text { international level by the UNESCO } \\
\text { Commission on World Natural and } \\
\text { Cultural Heritage is analyzed. }\end{array}$ \\
\hline $\begin{array}{l}\text { Step 3: World } \\
\text { best practices for } \\
\text { stabilizing the } \\
\text { environmental } \\
\text { situation }\end{array}$ & $\begin{array}{l}\text { Protection of nature, sustainable } \\
\text { environmental management }\end{array}$ & $\begin{array}{l}\text { The best international practices in } \\
\text { other lake regions have been studied in } \\
\text { the following areas: government } \\
\text { administration, opportunities for large } \\
\text { industries, business impact on the } \\
\text { environmental situation, NGO work to } \\
\text { improve the situation }\end{array}$ \\
\hline $\begin{array}{l}\text { Step 4: Visionary: } \\
\text { the future we } \\
\text { want. }\end{array}$ & $\begin{array}{l}\text { Axiological values: love for the nature of } \\
\text { the native land }\end{array}$ & $\begin{array}{l}\text { Making the desired image of the } \\
\text { region in the short term ( } 2 \text { years) and } \\
\text { in the long term (up to } 10 \text { years) }\end{array}$ \\
\hline $\begin{array}{l}\text { Step 5: Roadmap } \\
\text { for achieving the } \\
\text { goal }\end{array}$ & Personal and action-oriented approaches & $\begin{array}{l}\text { Drawing up a step-by-step road map of } \\
\text { desirable positive changes in the } \\
\text { following areas: finding fresh } \\
\text { approaches and projects to eliminate } \\
\text { accumulated environmental damage, } \\
\text { working with local communities, } \\
\text { transforming federal and regional } \\
\text { legislation to achieve the desired } \\
\text { changes in the shortest possible time }\end{array}$ \\
\hline $\begin{array}{l}\text { Step 6: Resource } \\
\text { definition }\end{array}$ & $\begin{array}{l}\text { Structural-functional model: purpose, } \\
\text { content, motivation, activity, evaluation, } \\
\text { reflexion }\end{array}$ & $\begin{array}{l}\text { The necessary funding and other } \\
\text { resources have been identified. } \\
\text { Persons responsible for the } \\
\text { implementation of each direction and } \\
\text { action have been identified }\end{array}$ \\
\hline
\end{tabular}

The project was carried out by a temporary creative team, whose term of activity was finite and limited to the final date of presentation of the completed project - this is the main condition of the project approach.

Stages of work in the project:

(1) creation of a workable team; (2) task definition; (3) creation of a road map of work; (4) distribution of responsibilities for short periods of time; (5) coordination of work by the head of the research team; (6) assembly of ready parts of the project by the head; (7) preparation of the final report and presentation for speech; (8) presentation of the results of the project study (speech before the expert community); (9) reflection, comparison of its 
results with the results of other working groups; (10) introduction of expert corrections; (11) presentation of the results of the project to the expert community.

Composition of the game teams: head - member of the youth government of the region, team members - students of local colleges and universities, studying in different areas of training, research director and tutor - teacher of the university or college and director of the department of one of the local ministries. This team structure ensures the involvement of different age groups, correct problem setting, and a significant improvement in the quality of the expected design result.

The working groups (teams of players) were named exactly as the main directions of the World Water Forum:

Climate - water security and climate change (team captain - understudy minister of ecology and nature management of the region, mentor - minister of ecology and nature management of the region). People - water supply, sanitation and health (captain of the understudy team, mentor to the Minister of Social Development). Growth - water for sustainable production (team captain, understudy of the Minister of Economic Development, mentor, Minister of Economic Development). Quality - water quality, wastewater and reuse (team captain, understudy team captain, mentor, Minister of Health). Ecosystems - water and ecosystems (team captain, understudy of the Minister of Social Development, mentor, Minister of Social Development). Management - water management (team captain - head of Youth understudy government, mentor - governor of Irkutsk region). Sharing - attraction of stakeholders at all levels to share the benefits provided by water resources (team captain - understudy minister of sports and youth, mentor - minister of social development). Capacity - education, capacity building and technology transfer (team captain - understudy minister of culture, mentor minister of culture). Financing - implementation of decisions (team captain - understudy of the Minister of Property Relations, mentor - Minister of Property Relations).

The teams consisted of college pupils and students, master's and postgraduate students of the local three universities.

The guidelines for the model contained a presentation guide, which was approximately the same for each working group. A sample is given for the "Climate" group:

Slide 1. Title. Name of the team. Logo of the university or department. Team composition (can be from players' photos). Slide 2. Review of the world climate theme and attempts to address it at the present stage. Use the above references in the report, it is very good to know the texture of the issue for successful further discussion. Slide 3. Overview of organizations leading hydrometeorological surveillance in the Baikal region, where they publish their data. Slide 4. Relevance of climatic subjects for Baikal region. What climatic changes are really taking place and what are the observed consequences? Slide 5. Brief review of literary data on scientific journals (find and prepare independently), not from mass media, on real climate problems and forecasts of changes in natural parameters in the region. Slide 6. Overview of local and federal climate change mitigation measures, from legislation to actual stoppage or conversion or re-profiling of businesses to mitigate climate impacts. Consider literally everything: the impact of housing and utilities, transport, enterprises and other agents. Reflect the subject matter of all the paragraphs mentioned above in this paragraph. Slide 7. Analysis of measures taken and identification of their weaknesses and non-performing positions. Slide 8. Analysis of the activities of existing local regional state protected areas (Specially Protected Areas) and NGOs engaged in "climate" activities (landscaping, Bird Days, restoration of plant nurseries, conservation of natural landscapes, implementing large and long term natural projects, such as WWF and others), etc. Slide 9. Own proposals for climate change mitigation at the regional level: presentation of 1-3 specific programs (e.g. conversion of boilers to partially use alternative energy; conversion of enterprises to other products; development of volunteer tour routes with restoration of natural flora of the region, etc.) and seeking targeted funding (it is necessary to be convincing for potential sponsors, even if the 
state can partially sponsor). Projects should be well developed, but not disclosed in detail, this will be necessary for further polemics and discussion. Slides 10-12. Own bold and creative proposals on how to increase and qualitatively improve the Baikal region's contribution to reducing global climate risks. Proposals may be general in nature, but they look more solid when they contain step-by-step targeted recommendations to different agencies. Slide 13. Literary sources. Slide 14. Acknowledgements to managers and organizations.

In addition, for the presentation, each working group prepared an analytical review (in the form of a printed document) of its topics on the clear recommendations of the Water Forum for its real participants.

The work of the teams was carried out by the members of the expert jury, filling in the evaluation sheets on the following items: knowledge of the invoice of the main material on the topic, completeness of the disclosure of the topic, the quality and addressability of the developed recommendations, the quality of the report and presentation, updating of information for the Baikal region, the quality and informativeness of the presentation, the quality of questions asked to other teams, the work of the players during the answers to the questions. Each team was sure to receive these sheets according to the results of the Model and could carry out reflection of its work according to the records of each member of the jury.

\section{Results and Discussion}

The concept of the project approach [6-7] allowed consolidating society and youth community in the region around a sensitive problem - deterioration of the ecological condition of Lake Baikal and its possible removal from the World Natural and Cultural Heritage List. Critical thinking was formed, which was significantly hampered by the formal educational process and outdated approaches to learning. From the point of view of knowledge and competence approach, the technology of actual problem setting and search of rational ways of its solution were pumped up. At youth skill of modeling of a situation, bases of management of the project of the decision of problems deconsolidated on segments is formulated. The skill of collective work, communication with various audiences and people with different level of thinking and competence is formed.

The possibilities and limitations of direct and feedback relationships between all Model participants were studied; the relationships in the emerging researchers' "ecosystem" were defined; the boundaries of competence and real level of material possession by research areas (working groups) were defined.

The level of readiness of educational organizations in the region and their motivation for integration into the world educational environment (space) and their ability to constantly saturate the labor market with specialists capable of solving urgent tasks of modern economy have been determined [8].

The project was implemented on the site of the First International Baikal Water Forum in 2017, on the threshold of the WWF in Brazil.

\section{Conclusions}

Practical experience in implementation of environmental education for sustainable development (ESD) has been developed; pedagogical technologies for informal work have been developed; pedagogical model of interaction between different segments of youth organizations, region's management and NGOs for effective environmental work in the region has been created; innovative directions in pedagogical activity have been identified, 
which are relevant in connection with adaptation of the global SDG agenda to regional processes.

\section{References}

1. J. Field, Lifelong Learning and the New Educational Order. Stoke on Trent (2000)

2. A. Sureka, M. Gupta, D. Sarkar, V. Chaudhary, A Case- Study on Teaching Undergraduate-Level Software Engineering Course Using Inverted-Classroom, LargeGroup, Real-Client and Studio-Based Instruction Model ( $1^{\text {st }}$ International Workshop on Case Method for Computing Education, 2015). URL: http://ceur-ws.org/Vol1519/paper15.pdf

3. Z. Masood, R. Hoda, K. Blincoe, J. of Systems and Software, 144, 501-510 (2018).

4. I. Noguera, A-E. Guerrero-Roldan, R. Maso, Computers \& Education, 116, 110-129 (2018).

5. M. Cubric, The Int. J. of Management Education, 11(3), 119-131 (2013).

6. E.V. Protopopov, A.V. Feoktistov, M.V. Temlyblev, O.V. Gordeeva, M.B. Vasilieva, Bull. of SibGIU, 4(22), 63-69 (2017) (in Russian).

7. M.V. Fominykh, B.A. Uskova, V.V. Mantulenko, O.N. Kuzmina, E.N. Shuravina, Int. Electron. J. of Mathematics Education, 11(8), 2814-2840 (2016).

8. E.F. Zeer, A.V. Streltsov, Int. Electron. J. of Mathematics Education, 11(7), 2639-2650. (2016). 